rewarding for both partners. Kissing and caressing sensitive areas (which may be especially sensitive in someone with sensory loss elsewhere) can be highly pleasurable, and some even report phantom or "mental" orgasms. ${ }^{1+}$ The increasing reliance on reflex mechanisms places greater emphasis on genital stimulation. ${ }^{1+}$

Published reports tend to concentrate on the effects on male sexuality, though women are likely to be similarly affected, intercourse sometimes producing painful spasms. ${ }^{5}$ Though recent studies ${ }^{15-17}$ do not support Guttman's original suggestion of an increased incidence of divorce among paraplegic patients, ${ }^{18}$ women are more likely to lose their partners than men. ${ }^{19}$ Naturally, spinal cord injuries put a strain on any relationship, which is not helped by a frustrated preoccupation with sexuality. Clearly, however, such frustration is needless and there is great potential for paraplegic patients to have full and satisfying sexual relationships. This makes it all the more important that information, support, and counselling are available.

J M KELLETT

Senior Lecturer, Department of Geriatrics,

St George's Hospital Medical School, London SW17 0RE
1 Hanson RW, Franklin MR. Sexual loss in relation to other functional losses for spinal cord injured males. Archives of Rehabilitation 1976;57:291-3

2 Ray C, West J. Social, sexual and personal implications of paraplegia. Paraplegia 1984;22:75-86

3 Slot D, Drewes A, Andreason A, Olsson D. Erectile and ejaculatory function of males with spinal cord injury. Int Disabil Stud 1990;11:75-7.

+ Verkyl A. Sexual function in paraplegia and tetraplegia. Handbook of clinical neurolog 1976;29:437-61.

5 Phelps G, Brown $M$, Chen J, et al. Sexual experience and plasma testosterone levels in male veterans after spinal cord injury. Arch Phys. Med Rehabil 1983;64:47-52.

6 Bors $\mathrm{E}$, Comarr AE. Neurological disturbances of sexual function with special reference to 529 patients with spinal cord injury. Urological Survey 1960;10:191-222.

Sjögren $\mathrm{K}$, Egberg $\mathrm{K}$. The sexual experience in younger males with complete spinal cord injury. Scand f Rehabil Med 1983:9 (suppl):189-94.

Nikas V, Fleischman P, Burton P. Sexual and marital adjustment of world war II spinal cord injured veterans. Paraplegia 1990;28:164-71.

injured veterans. Paraplegia 1990;28:164-71.
Francois N, Maury M. Sexual aspects in paraplegic patients. Paraplegia 1987;25:289-92.

10 Schuler M. Sexual counselling for the spinal cord injury; a review of five programmes. F Sex Marital Ther 1982;8:241-52.

11 Daniels S, Cornelius D, Makas E, Chipouras S. Who cares? A handbook on sex education and counselling services for disabled people. Washington, DC: Sex and Disability Project, 1979

2 Virag R, Frydman D, Legman $M$, Virag H. Intracavernous injection of papaverine as a diagnostic and therapeutic method in erectile failure. Angiology 1984;35:79-87.

13 Talbot HS. The sexual function in paraplegia. Urology 1955;73:91-100.

14 Berard EJJ. The sexuality of spinal cord injured women: physiology and pathophysiology. A review. Paraplegia 1989:27:99-112.

15 Devve FS. Marriage and family patterns with long term spinal cord injury. Paraplegia 1972;10:21924.

16 Larsen E, Hejgaard N. Sexual dysfunction after spinal cord or cauda equina lesions. Paraplegia $1984 ; 22: 66-74$.

17 Ungar G. Children, marriage and marital outcome in the spinally injured. Paraplegia 1987;25:425 -

18 Guttman L. The married life of paraplegics and tetraplegics. Paraplegia 1964;2:182-8.

19 Baxter R. Divorce, the second trauma. In: Cheever RC, ed. Accent on living. Bloomington, Illinois: Raymond C Cheever, 1981:46-52.

\title{
Juniors' hours: measuring the strength of feeling
}

\section{Without support negotiators will fail to shorten working hours}

Two out of three junior hospital doctors are contracted to work over 77 hours a week ${ }^{1}$ despite abundant evidence that working such long hours seriously affects their morale and performance. ${ }^{2-8}$ Few would dispute the Secretary of State for Health's description of the working conditions of junior medical staff as "barbaric" or that of his Minister for Health, Virginia Bottomley, as "impossible to defend."

Despite agreement among doctors, NHS managers, and the Department of Health attempts at achieving change through local working parties, central direction, and pay mechanisms have not met with much success. Hopes are now pinned on the latest initiative - a working party set up by Mrs Bottomley, which has been asked to offer definitive solutions before Christmas.

A simple solution seems unlikely: if one existed it would have been adopted long ago. All parties to the talks, however, agree that no substantial change can occur until medical manpower, particularly in the consultant grade, is increased. Ways of using junior doctors' time and skills more flexibly and efficiently - for example, shift and partial shift systems - all leave gaps in providing for the daytime service, which would need filling if the services were not to suffer. ${ }^{11}$ Funding more consultants is, of course, the responsibility of the Department of Health, which would also have to ensure that the new posts were established where they were needed as a consequence of reducing juniors' hours. This will cost money, which should be partially recouped by increased efficiency, morale, and performance. Services to patients should also improve as more direct care is provided by fully trained doctors.

Persuading the government in the current economic climate to devote scarce financial resources to reducing juniors' hours of work is difficult, and this is where the juniors' survey comes in. Juniors' leaders need to be able to show how strongly their constituents feel about the problem, which is why juniors who are members of the BMA have been asked what actions they would be prepared to take in support of shorter working hours. ${ }^{12}$ The Hospital Junior Staff Committee is taking an appreciable risk: juniors' participation in similar activities, particularly postal elections, has usually been poor. ${ }^{13}$

Much is at stake this time. Without the active support of their constituents juniors' leaders may find it impossible to convince the ministerial working party of the need for urgent change. If they fail then the status quo will probably prevail for the forseeable future. If junior doctors care about their hours of work then they will complete the postal survey and return it to BMA House by 12 November.

Chairman,

STEPHEN HUNTER

Hospital Junior Staff Committee,

British Medical Association,

London WC1H 9JP

1 Review Body on Doctors' and Dentists' Remuneration. 20th Review, London: HMSO, 1989. (Statistical evidence from the health departments. Table GEN 3F.)

Allen I. Doctors and their careers. London: Policy Studies Institute, 1989.

Dowie R. Patterns of hospital medical staffing: interim report junior doctors' hours. London: British Postgraduate Medical Federation, 1990.

Spurgeon $\mathrm{A}$, Harrington JM. Work performance and health of junior hospital doctors-a review of the literature. Work and stress 1989;3:117-28.

Leslie PJ, Williams JA, McKenna C, Smith G, Heading RC. Hours, volume, and type of work of preregistration house officers. BMF 1990;300:1038-41

6 Dent THS, Gillard JH, Aaarons EJ, Crimlisk HL, Smyth-Pygot PJ. Preregistration house officers in the four Thames regions: 1 . Survey of education and workload: 2 . Comparison of education and workload in teaching and non-teaching hospitals. $B M \mathcal{A} 1990 ; 300: 713-8$.

7 Firth-Cozens J. Emotional distress in junior house officers. BMF 1987;295:533-6.

8 Firth-Cozens J. Stress in medical undergraduates and house officers. Br f Hosp Med 1989;41:161-4.

9 Anonymous. Clarke backs junior doctors. Today $199015 \mathrm{Mar}: 4$ (col 7).

10 Smith A Summit called to slash junior doctors' hours. Sunday Express $199025 \mathrm{Mar}: 7$ (cols 1-3).

11 Finn A, Speidel BD. Shift system for senior house officer on call duties on a neonatal intensive care unit. BM7 1988:296:343-4.

Delamothe T. Junior doctors' hours: What do juniors think? BM7 1990;301:891.

13 Field IT. Council election results. BMF 1990;300:1403-4. 